\title{
Intellectual Capital and Firm Performance: Empirical Evidence from the Jakarta Islamic Index
}

\author{
Prasojo \\ Faculty of Economic and Islamic Business \\ UIN Sunan Kalijaga \\ Sofyan Hadinata \\ Faculty of Economic and Islamic Business \\ UIN Sunan Kalijaga
}

\begin{abstract}
Measurement of intellectual capital is fundamentally crucial for companies. It enables managers to allocate economic resources to improve knowledge assets in order to support a sustainable competitive advantage for the companies. This study presents a method of residual income model (RIM) to measure intellectual capital (IC). This method quantitatively assesses intellectual capital using knowledge-based view perspective. Purpose of the study is to examine the relationship of intellectual capital with company financial performance empirically. This study uses panel data regression with research objects listed in the Jakarta Islamic Index from 2014 to 2017. The results of this study indicate that intellectual capital does not affect the company's financial performance.
\end{abstract}

Keywords: intellectual capital; residual income model; knowledge-based view; Jakarta Islamic Indeks

\section{Introduction}

In the era, new economic, primarily intangible organizational resources contributed more to maintaining superior positions (Barney, 1991). According to Bontis (1998), intellectual capital (IC) is an intangible asset that can generate profits but is not appropriate in the company's financial statements. Organizations that can create consistent innovation in terms of business processes or the creation of new products will be more likely to maintain a competitive advantage (Tidd, Bessant, \& Pavitt, 2005). Companies must be able to encourage increased employee competence to encourage innovation that can create corporate excellence (Roos, Roos, Edvinsson, and Dragonetti, 1997). Cabrita, Silva, Rodrigues, \& Dueñas (2017) argue that the continuity of the company depends on the ability of IC companies in the form of the ability to innovate, competence, customer service, and organizational intelligence.
The resource-based theory holds that company performance depends on the ability of companies to manage tangible assets and intangible assets owned. Physical capital and human capital are the leading resources in the traditional economic outlook for productive activities of the company (Nahapiet \& Ghoshal, 1998). According to Subramaniam \& Youndt (2005), IC is an intangible asset that is important in supporting business sustainability. IC has an impact on performance because it is based on unique knowledge and is difficult for other companies to duplicate (Barney, 1991).

Many kinds of literature reveal various IC concepts and their impact on competitive advantage and performance. Furthermore, IC can be grouped into three dimensions consisting of human capital (HC), structural capital (SC), and relational capital (RC), which are accepted by the majority of researchers such as (Bontis, Keow, \& Richardson, 2000; Edvinsson and Malone, 1997; Edvinsson \& Sullivan, 1996; Roos, Roos, Edvinsson, and 
Dragonetti, 1997; Sveiby, 1997). Nevertheless, the results of the study found different results if each of the components were tested respectively. Edvinsson and Malone (1997) classify intellectual capital into human capital and structural capital. Roos, Pike, and Fernstrom (2005) grouped IC into three dimensions, namely human capital, structural capital, and relational capital. So that allocating the right investment in the IC component becomes a vital factor for positioning the company's business strategy (Kong \& Ramia, 2010). Some researchers try to provide a broad picture of the intellectual capital valuation model (Bontis, 2001; Wall et al., 2003). Concerning the existing valuation model, Sveiby (2001) in Sydler et al. (2014) introduces a two-dimensional matrix explicitly, describing IC valuation models according to their level of assessment (organizational or component level) and about methods (non-monetary and monetary).

Literature that links IC and the performance of Sharia-based nonfinancial companies is still small, especially in Indonesia. There are several reasons why research uses sharia. First, the screening process carried out by the IDX at least provides certainty for investors that the selection of companies that enter the JII is a company selected with specific criteria. Second, according to sharia principles, companies should not only pursue financial profit (profit) but also must pay attention to environmental aspects (planet) and also people (people). The concept of the intellectual model is inseparable from the human element, so it is interesting to examine more deeply how intellectual capital can affect company performance in companies registered with ISSI. Thirdly, the encouraging development of the Islamic capital market in Indonesia also attracts researchers to conduct research. Sharia shares are the most actively traded categories on the Indonesia Stock Exchange, namely the JII (Jakarta Islam Index) category. The researchers guess that the companies included in JII have profitability above the industry average, so they are actively traded and have a tremendous intellectual capital composition.

There are two types of sharia shares recognized in the Indonesian capital market (IDX). First, stocks that meet the sharia stock selection criteria based on OJK regulation No. II.K.1 concerning the issuance of sharia securities list, the second is shares listed as sharia shares by issuers or sharia public companies based on OJK regulations Number 17 / POJK.04 / 2015. All sharia shares registered on the Indonesian Syariah Capital Market are listed on the IDX, is entered into the Sharia Securities List (DES) issued by the OJK regularly, every May and November. The Jakarta Islam Index (JII) is the first Shariah stock index to be launched on the IDX on July 3 , 2000. JII only consists of 30 of the most liquid shariah shares listed on the IDX (idx.co.id).

This study uses a valuation model from previous research that uses a financial performance model, in the financial performance model we will use a model with financial statement data (Sydler, Haefliger, \& Pruksa, 2014). Based on a suggestion from a previous author, Sydler et al. (2014), each variable of intellectual capital is represented by one indicator. According to Sydler et al. (2014) that research on companies in one country will make the model more accurate and reliable because if different countries, it is challenging because of the different legal and risks, such as the risk of currency differences, country policy risk, and others. The research aims to analyze the relationship between IC and company performance included in the JII index. This research makes an essential contribution to the company's obligations on intellectual capital, such as training for employees, supporting infrastructure, processes, organizational databases that enable human capital to carry out its duties or functions, copyright, licensing, and others. With the allocation of intellectual 
capital, the company's sustainability in the future will be guaranteed because it will be able to compete with other companies.

\section{Literature Review and Hypothesis Development}

Edvinsson and Malone (1997) define IC as a knowledge asset that can be converted into value-added companies. Whereas Stewart (1997) argues that IC is the accumulation of science, company information, property rights and individual experience in organizations include patents, business processes, knowledge management, technology, and data of customers and suppliers. Castro (2014) classifies IC into three sub-components, namely $\mathrm{HC}, \mathrm{SC}$, and CC (customer capital). HC represents the abilities, knowledge, skills, expertise, and experience of employees that can be utilized by the company in achieving its objectives. SC is the deposition of employee knowledge identified in the company system (Roos, Bainbridge, \& Jacobsen, 2001). SC is an infrastructure built by human resources by transferring knowledge into intangible assets. $\mathrm{SC}$ can be in the form of procedure, structure, culture (Bontis, 1998).

Human resources are an essential asset of the company because they can create added value (Dotzel, Shankar, \& Berry, 2013). Companies that have human resources with higher skills and education tend to have better performance (Hsu, \& Fang, 2009). Prajogo \& Oke (2016) said that companies that develop their human resources by increasing knowledge and skills would increase creativity and generate new ideas that will result in improved performance. Human capital investment is positively related to firm performance (Nawaz, 2019). The measurement of human capital is difficult because of the unavailability of market prices. Wakelin (1998) said the company's human capital could receive the amount of compensation the company receives.
R\&D expenditure can increase the value of the company because these activities can create new assets (Chan, Kensinger, \& Martin, 1992). Previous research has found evidence that $R \& D$ expenditures have a positive impact on a company's market value (Bandeira \& Afonso, 2010; Coombs \& Iii, 2005; DeCarolis, D. M., \& Deeds, 1999; Lev \& Sougiannis, 1996). Sydler et al. (2014) said $\mathrm{R} \& \mathrm{D}$ expenditure is an appropriate measure to describe structural capital.

Advertising expenditures are positive for increasing market value (Klock \& Megna, 2000). The market responds to advertising expenditure as a relational capital investment because it has a positive impact on the company's future cash flow (Barnett \& Salomon, 2006). The company advertises to increase brand value in the market so that it will increase customer loyalty. Companies with high customer loyalty will increase the trading volume so that it is easier to win marketing competitions (Leslie, M., \& Holloway, 2006). Sydler et al. (2014) argue that advertising expenses are an appropriate proxy for measuring relational capital. The advertising expenses invested can provide benefits for the company in the future, so that it can reflect the definition of customer capital.

Research that links IC with company performance is still being contested, so it is still interesting to develop further (Tasawar Nawaz, 2017). Previous research results like Kharal et al. (2014) this study found that IC positively affected performance specifically in the oil and gas industry Pakistan. Ozkan, Cakan, \& Kayacan (2017) found that human capital (HCE) had a positive effect on banking performance in Turkey. Lu, Wang, \& Kweh (2014) said that IC had a positive impact on the performance of insurance companies in China. Sardo \& Serrasqueiro (2017) said IC is positively related to financial and market performance as measured by ROA and Tobin's Q. Kim \& Taylor (2014) said that productivity of $\mathrm{HC}, \mathrm{SC}$ and Capital Employed Efficiency 
(CEE), each positive and significant effect to stock prices. However, compared with total assets to book value, the results are not significant.

Another study conducted by Kim \& Taylor (2014) results showed that the productivity of $\mathrm{HC}, \mathrm{SC}$, and $\mathrm{CEE}$ each had a significant and positive effect on stock prices while the productivity of total assets was not significant on stock prices. This research was conducted on 160 companies listed on the Australian Exchange. Tiwari \& Vidyarthi (2018) the results of his study stated that there is a positive relationship between IC and bank performance. In particular, $\mathrm{HC}$ and SC showed a significant positive on the performance of banks while the IC efficiency of private banks was better than government banks in India. Research conducted on 34 banks in India in 1999-2015. Joshi, Cahill, \& Sidhu (2010) found evidence that VAIC has a significant relationship with personal costs (HC) and VA in banks in Australia. Whereas total assets, number of employees, bank size, and total equity have no impact on bank performance. Al-Musali \& Ismail (2016) the results of his study found that IC has a related positive on bank financial performance indicators in all GCC countries. While partially if the IC component is tested with financial indicators, the results vary.

While the results of Nawaz \& Roszaini (2017) say that a positive relationship VAIC and accounting performance (ROA), however, for SC indicators, there is no significant ROA, therefore, it can be concluded that the ability to create corporate VA is strongly influenced by HCS and CEE. Hamdan (2018) found evidence supporting the relationship between IC and market-based. Research carried out in Saudi Arabia and Bahrain, and further analysis also revealed different results between these countries.

Empirically $\mathrm{HC}$ is considered to affect performance positively, and the results of previous studies have been collected to support this claim. As a study conducted by Chen, Cheng, \& Hwang (2005) shows that human resources have a positive effect on market value and company profitability, this study was conducted in Taiwan. Kamath (2007) found evidence that $\mathrm{HC}$ has a significant impact on the profitability and productivity of pharmaceutical companies in India. Ting \& Lean (2009) shows that $\mathrm{HC}$ has a positive impact on profitability (ROA). This study was conducted at financial institutions in Malaysia.

However, the conflicting study results also found by Chu, Chan, \& Wu (2011) found evidence that $\mathrm{HC}$ harms stock market performance, but positively on profitability (ROA). Whereas if it is associated with the performance impact measured by shareholder return (ROE) and productivity (ATO) is not significant. In contrast, Maditinos, Chatzoudes, Tsairidis, \& Theriou's (2011) study results show a positive relationship between $\mathrm{HC}$ with market performance and ROE, whereas if it is associated with ROA and company growth has no impact.

Previous research linking IC to performance has mostly focused on a corporate listing in the capital market (Anifowose, Rashid, \& Annuar, 2017; Hamdan, 2018) and Islamic banking (Helmi, \& Mustafa, 2019; Nawaz, 2017, 2019; Nawaz \& Roszaini, 2017). This paper is more focused on companies included in the category of sharia companies. In the context of Indonesia, companies that are included in Sharia screening and are most actively traded are included in the JII index. Companies in the Syariah category are much sought after by investors, as reflected in the volume of stock trading transactions. Therefore, companies in the sharia category are expected to be able to manage and utilize their IC so that they can meet investor expectations to produce better company performance. Based on the above discussion, the following hypotheses can be formulated:

Hypothesis: intellectual capital has a positive effect on financial performance 


\section{Methodology, Data and Analysis}

This study uses secondary data from company annual reports obtained from the website idx.co.id and the website of each company. The population in this study there are companies listed on JII. As for sampling, this study uses a purposive sampling method. The criteria used by researchers are companies that are consistently registered in JII in the 2015-2017 period. Another criterion is that companies disclose more data in the annual report as supporting data needed in this study. Based on the criteria determined above the samples that met the criteria were 16 companies with a total of 48 observations. The following is a list of companies that met the criteria used as samples in this study:

Table 1. List of Sample

\begin{tabular}{|c|c|c|}
\hline No & Company Code & Company Name \\
\hline 1 & ADRO & Adaro Energy Tbk \\
\hline 2 & AKRA & AKR Corporindo Tbk \\
\hline 3 & ASII & Astra International Tbk \\
\hline 4 & BSDE & Bumi Serpong Damai Tbk \\
\hline 5 & ICBP & Indofood CBP Sukses Makmur Tbk \\
\hline 6 & INDF & Indofood Sukses Makmur Tbk \\
\hline 7 & KLBF & Kalbe Farma Tbk \\
\hline 8 & LPKR & Lippo Karawaci Tbk \\
\hline 9 & LSIP & Perusahaan Perkebunan London Sumatra Tbk \\
\hline 10 & PGAS & Perusahaan Gas Negara Tbk \\
\hline 11 & SMGR & Semen Indonesia (Persero) Tbk \\
\hline 12 & SMRA & Summarecon Agung Tbk \\
\hline 13 & TLKM & Telekomunikasi Indonesia (Persero) Tbk \\
\hline 14 & UNTR & United Tractors Tbk \\
\hline 15 & UNVR & Unilever Indonesia Tbk \\
\hline 16 & WIKA & Wijaya Karya (Persero) Tbk \\
\hline
\end{tabular}

This study uses the dependent variable profitability, while the independent variable is intellectual capital. Measurement of variables for company performance is to use modified ROA for book values to reduce heteroscedasticity, whereas the independent variable is measured by the modified RIM model (Sydler et al., 2014). Furthermore, the original RIM (Ohlson, 1995) was modified to explicitly include investment in human, structural and relational capital used in this study.

Intellectual capital (IC) Model assets use the following formula:

$$
\begin{aligned}
\mathrm{IC} & =\alpha\left(\mathrm{H}_{\mathrm{t}}+\mathrm{S}_{\mathrm{t}}+\mathrm{R}_{\mathrm{t}}\right)+(1-\delta)\left(\mathrm{IC}_{\mathrm{t}-1}\right) \\
& =\alpha\left(\mathrm{IE}_{\mathrm{t}}\right)+(1-\delta)\left(\mathrm{IC}_{\mathrm{t}-1}\right) \ldots \ldots \ldots \ldots \ldots \ldots
\end{aligned}
$$

IC is intellectual capital at time $t, \alpha$ is the accumulation level $(0<\alpha<1), \delta$ is the amortization level $(0<\delta<1)$ cost, Ht is human capital (personal cost) at time t, St is $R \& D$ at time $t, R t$ is the advertising expense at the time, and $t$ the cost of creating intellectual capital. We can use the form $\mathrm{IC}_{\mathrm{t}-1}=\alpha \phi\left(\mathrm{IE}_{\mathrm{t}-1}\right), \phi=(1+g / \delta+g)$, $g=$ risk-free rate, uses the Bank Indonesia interest rate reference 4,25 .

Referring to Sydler's (2014) research, we apply panel data analysis (longitudinal data) to the model in equation (2) and determine all the coefficients of the model. Furthermore, the calculated A3 and A4 coefficients are used to calculate through a system of linear equations, the desired variable $\alpha$ (accumulation rate) and $\delta$ 
(amortization rate) used as a basis in IC calculations (listed in model 1). As stated, $\alpha$ and $\delta$ are assumed to lie between 0 and 1 .

$$
\begin{array}{r}
\frac{\mathrm{MVt}}{\mathrm{MVt}-1}=\mathrm{A} 0+\mathrm{A} 1 \frac{\mathrm{BVt}}{\mathrm{BVt}-1}+\mathrm{A} 2 \frac{\mathrm{NIt}}{\mathrm{BVt}-1}+ \\
\mathrm{A} 3 \frac{\mathrm{IEt}}{\mathrm{BVt}-1}+\mathrm{A} 4 \frac{\mathrm{IEt}-1}{\mathrm{BVt}-1}+\varepsilon \ldots \ldots \ldots \ldots \ldots \ldots \ldots \ldots \ldots \ldots \ldots \ldots \ldots \ldots \ldots \ldots \ldots
\end{array}
$$

In analyzing the effect of intellectual capital on profitability, we use model 3, as used by Sydler et al. (2014). Transformation is used here to reduce the problem of heterokedasitas. We divide the dependent variable return on assets (ROA) and the independent variable intellectual capital (ICpt) based on the appropriate book value (BV) and then carry out the following logarithms:

$$
\log \left(\frac{\mathrm{ROAt}}{\mathrm{BVt}}\right)=\mathrm{A} 0+\mathrm{A} 1 \log \left(\frac{\mathrm{ICt}}{\mathrm{BVt}}\right)
$$

Table 2. Description of the research variables

\begin{tabular}{lll}
\hline \multicolumn{1}{c}{ Symbol } & \multicolumn{1}{c}{ Name } & \multicolumn{1}{c}{ Description } \\
\hline IEt & $\begin{array}{l}\text { Intellectual capital-creating } \\
\text { expenses }\end{array}$ & $\begin{array}{l}\text { Total labour costs, R\&D expenditures and advertising } \\
\text { costs }\end{array}$ \\
\hline IEt-1 & $\begin{array}{l}\text { Intellectual capital-creating } \\
\text { expenses for t-1 }\end{array}$ & $\begin{array}{l}\text { Total labour costs, R\&D expenditures and advertising } \\
\text { costs for period } \mathrm{t}-1\end{array}$ \\
\hline $\mathrm{BVt}$ & Book value per share & Total equity/number of shares outstanding \\
\hline $\mathrm{MVt}$ & $\begin{array}{l}\text { The average share price for } \\
\text { ten days at the end of the } \\
\text { year }\end{array}$ & The price of the last ten days in each year \\
\hline ROA & Return on asset & $\begin{array}{l}\text { Net income before extraordinary items - minority } \\
\text { rights / average total assets }\end{array}$ \\
\hline rf & Risk-free interest & uses the Bank Indonesia interest rate reference \\
\hline ICt & Intellectual capital in year t & - \\
\hline
\end{tabular}

\section{Result and Discussion}

Based on the results of the data analysis obtained, descriptive statistical results are listed in Table 3. Descriptive statistics provide a general description of the data, which includes the number of observations, average, standard deviation, minimum, and maximum.

Table 3. Descriptive Statistics

\begin{tabular}{lrrrrr}
\hline \multicolumn{1}{c}{ Variable } & Obs & \multicolumn{1}{c}{ Mean } & Std. Dev. & \multicolumn{1}{c}{ Min } & \multicolumn{1}{c}{ Max } \\
\hline MV & 48 & $7.567,2320$ & $11.180,0900$ & 449,5000 & $54.042,5000$ \\
BV & 48 & $2.486,4920$ & $2.773,4550$ & 233,3500 & $12.744,2900$ \\
BVt1 & 48 & $2.319,0330$ & $2.596,4020$ & 209,4400 & $11.426,3800$ \\
NI & 48 & 335,9940 & 389,4363 & 0,0300 & $2.000,0000$ \\
ICt & 48 & $2.982,5770$ & $3.259,1530$ & 224,8577 & $12.280,9000$ \\
ICt1 & 48 & $1.474,0450$ & $1.638,9880$ & 113,9061 & $6.342,7340$ \\
ROA & 48 & 8,6688 & 8,4159 & 1,0800 & 38,1600 \\
LogIEt & 47 & 3,2573 & 0,4570 & 2,3519 & 4,0892 \\
MVBVt1 & 48 & 5,9718 & 8,8230 & 0,3547 & 42,6485
\end{tabular}




\begin{tabular}{lrrrrr} 
BVBVt1 & 48 & 1,9623 & 2,1887 & 0,1842 & 10,0574 \\
NIBVt1 & 48 & 0,2652 & 0,3073 & 0,0000 & 1,5783 \\
IEBVt1 & 47 & 0,0032 & 0,0034 & 0,0003 & 0,0162 \\
IEt1BVt1 & 48 & 5,9392 & 6,4084 & 0,5016 & 25,1760 \\
LogROABV & 48 & $(2,4094)$ & 0,5578 & $(3,2269)$ & $(1,2028)$ \\
LogICBV & 48 & 0,5071 & 0,5016 & $(0,5237)$ & 1,5003 \\
\hline
\end{tabular}

This research focuses on testing the effect of intellectual capital on the company's financial performance. Data were analyzed using a square panel method with fixed effects using
STATA 16. Testing sample data, a panel data analysis with a significance level of $5 \%$ was performed.

Table 4. Summary Statistics for the Adjusted RIM Model

\begin{tabular}{lcc}
\hline \multicolumn{1}{c}{ Dependence Variable: $\log (\mathbf{R O A p t} / \mathbf{B V p t})$} & Coeff. & SE. \\
\hline Independence Variable: & & \\
BVt/BVt-1 & -0.57619 & {$[1.92994]$} \\
NIt/BVt-1 & $16.17709^{* * * *}$ & {$[4.71470]$} \\
IEt/BVt-1 & 0.27684 & {$[0.39485]$} \\
IEt-1/BVt-1 & -0.09261 & {$[0.32254]$} \\
cons & 1.47431 & {$[2.97312]$} \\
$N$ & 48 & \\
F Statistic & 6.35037 & \\
P-value F Statistic & 0.00091 & \\
R Square & 0.60957 & \\
${ }^{*} p<0.1,{ }^{* *} p<0.05^{* * *} p<0.01$ & &
\end{tabular}

From the analysis results in table 4 , the A3 coefficient is 0.27684 and A4 is -0.09261 . This number is used as the basis for the calculation of intellectual capital as listed in equation 1 .
The coefficient A3 is used as the parameter $\alpha$ (accumulation rate), and the A4 coefficient is used as $\delta$ (the amortization rate).

Tabel 5. Hypothesis Testing Result

\begin{tabular}{lcc}
\hline \multicolumn{1}{c}{ Dependence Variable: $\mathbf{L o g}(\mathbf{R O A p t} / \mathbf{B V p t})$} & Coeff. & SE. \\
\hline Independence Variable & & \\
Log(ICpt/BVpt) & 0.50634 & {$[0.32042]$} \\
cons & $-2.66612^{* * * *}$ & {$[0.16391]$} \\
$N$ & 48 & \\
F Statistic & 2.49705 & \\
P-value F Statistic & 0.12421 & \\
R Square ${ }^{*} p<0.1,{ }^{* *} p<0.05,{ }^{* * *} p<0.01$ & 0.26683 &
\end{tabular}

Based on table 5, show that intellectual capital does not affect financial performance. Part of the variable net income (NIBV) affects financial performance, while intellectual capital does not affect financial performance. In this study, intellectual capital is measured from the costs incurred consisting of employee costs (total costs) in the total of all costs associated with employees, namely salaries, remuneration, personal allowances (uniforms, insurance, pensions, transportation, overtime, meals), training costs the employee. The second is costs related to research and development (research cost) consisting of research and product 
development costs, including exploration costs for mining companies. The third is the cost of marketing (relational cost) which consists of advertising costs, including client meals and entertainment expenses.

Figure 2. Sample profiles according to industry categories

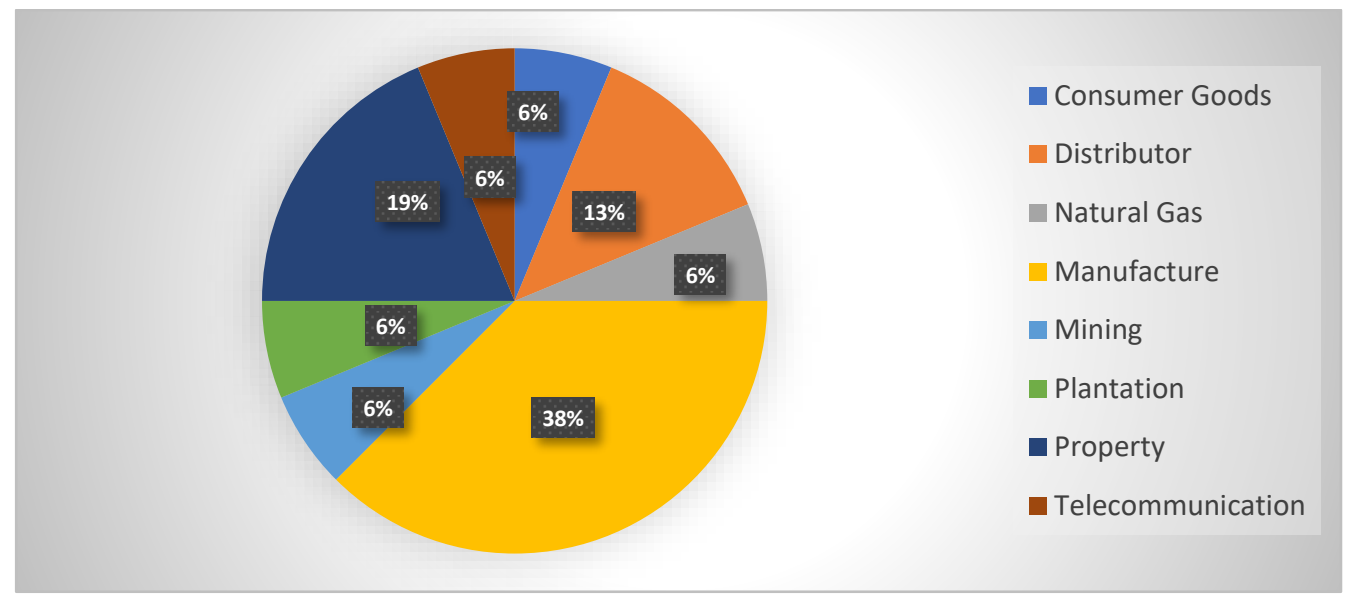

We observed 16 companies as a sample; the majority of the samples came from the property, manufacturing industry sector, distributor, and other sectors with the same percentage. According to Hirsch-Kreinsen, Jacobson, \& Robertson (2006) industry category if linked to $\mathrm{R} \& \mathrm{D}$ costs.

High-technology industries, where the $R \& D$ expenditure are at least $5 \%$ of the output, and they include the following industries: aircraft, spacecraft, pharmaceutical, office, accounting, and computing machinery, radio, TV, communication equipment and medical, precision, and optical instrument;

Medium-high-technology industries, where the R\&D expenditure are between $3 \%$ to $5 \%$ of the output and they include the following industries: electrical machinery and apparatus, motor vehicles trailers, semitrailers, chemicals excluding pharmaceuticals, railroad equipment and transport equipment, machinery and equipment;

Medium-low-technology industries, where the R\&D expenditure are between $0,9 \%$ to $3 \%$ of the output and they include the following industries: building and repairing of ships and boats, rubber and plastic product, coke, refined petroleum products and nuclear fuel, other non-metallic mineral products, and primary metal and fabricated metal product; Low-Technology industries, where the R\&D expenditure is less than $0,9 \%$ of the output, and they include the following industries: manufacturing and recycling, wood, pulp, paper product, printing and publishing, food product, beverage, tobacco, textile, textile product, leather and footwear.

Based on the above categories, the type of industry that becomes the sample is included in the category of low-technology industries except for Kalbe Farma Tbk which is a pharmaceutical industry which is included in the category of high-technology industries. In collecting costs related to intellectual capital, the authors experience difficulties because not all companies sampled reveal the costs of research and development in the company's annual report. Companies that do not disclose the costs of research and development include PT. AKR Korporindo Tbk, PT. Indofood CBP Sukses Makmur Tbk, PT. Bumi Serpong Damai Tbk, PT. Indofood Sukses Makmur Tbk, PT. Lippo Karawaci Tbk, PT. London Sumatra Indonesia Tbk Plantation, PT. Sumarecon 
Agung Tbk, PT. Telekomunikasi Indonesia (Persero) Tbk and PT. United Tractors Tbk. Companies that disclose the highest research and development costs are PT. The State Gas Company (Persero) Tbk, between 2015 and 2017 the company reported research and development costs of Rp. 7.840 billion. Then the second rank is PT. Adaro Energy Tbk, the company, reports research and development costs in the span of 2015-2017 reporting research and development costs of $\mathrm{Rp} 4,673$ billion.

In terms of expenditure for the personal cost, there was PT. Astra International Tbk as first ranks with total expenditure during the 2015-2017 period of Rp. 48,968. Billion. The second rank is occupied by PT. Telekomunikasi Indonesia (Persero) Tbk with a total expenditure of Rp. 40,338 during the 2015-2017 study period. In contrast, the third rank is occupied by PT. United Tractor Tbk with a total expenditure of Rp. 31,428 billion during the 2015-2017 period.

The company's advertising costs that spend the most advertising costs are PT. Telekomunikasi Indonesia (Persero) Tbk with total advertising costs for the period of 20152017 amounting to Rp. 12,675 billion. Then the second rank was occupied by PT. Kalbe Farma Tbk with a total expenditure of Rp 4,974 billion over the period 2015-2017. Moreover, the third rank is occupied by PT. Indofood Sukses Makmur Tbk with a total expenditure of Rp 4,463 billion during the 2015-2017 period.

Terms of performance as measured by earnings per share (EPS), PT United Tractors Tbk ranked first in achieving EPS with an average EPS of 2015-2017 amounting to Rp 1,464 per share. Then the second rank was obtained by PT. Unilever Indonesia Tbk by obtaining an average EPS from 2015-2017 amounting to Rp 849 per share. Furthermore, the third rank is achieved by PT. Semen Indonesia (Persero) Tbk with an average EPS acquisition from 2015-2017 amounting to Rp 625 per share.
Based on the sample studied, almost all of the highest cost companies are personal costs, then marketing costs and the last is research costs. In Indonesia, there is a paradigm shift about humanity that was once considered a resource now that many think that human is capital. This is reflected in the philosophy of changing names from Human Resources to Human Capital in several large companies such as Adaro Energy, Astra International, and Telkom.

Based on the results of the statistical findings in the study, intellectual capital does not affect the financial performance measured by using market performance, namely the average price of shares in the last ten days at the end of each year. This finding contradicts Sydler et al., (2014) that market behaviour is influenced by company spending for personal costs, research and development costs, and advertising costs that are treated as assets that have benefits significant for the company in the future. The results of this study are in line with research conducted by Nuryaman (2015) which shows that intellectual capital (VACA, VAHU, STVA, and VAIC) positively influences Return on Assets (ROA) not supported at a significance level of 0.05 . In the partial measurement of intellectual capital, Ozkan, Cakan, \& Kayacan (2016), Ting \& Lean (2009), and Joshi et al. (2013) failed to find evidence that structure capital efficiency (SEC) affected ROA. This result was not in line with the researchers' expectations, and this might be because the research analysis combined several types of industries so that the available data failed to describe the effect of intellectual capital on ROA.

According to the author's analysis, this is because not all companies carry out comprehensive disclosure of the components of intellectual capital. The author tries to ask for comments from one of the human capital head groups from a company in Indonesia. He argues that the company has designed and improved their respective competencies that are expected 
by users (related managers) to utilize these competencies to improve company performance which ultimately can improve the company's competitive advantage. However, in reality, many managers have not maximized these competencies in achieving company goals.

\section{Conclusion}

Our research provides evidence of intellectual capital that has not had a significant impact on the performance of companies included in the Jakarta Islamic Index (JII). This research model adopts one of the models developed (Sydler et $a l ., 2014)$. The model developed is quantitative with the RIM method, so it is hoped that the bias can be explored further.

This research still has many limitations, including a limited research period of only three years, the sample company consists of various industrial fields, so this affects creating intellectual capital, for example, the service industry costs a lot for personal costs and advertising, the mining industry costs a lot for research and exploration of mine reserves.

For subsequent studies, a larger sample can be used so that research results are robust, and the results can be generalized. Besides, subsequent research can use other intellectual capital valuation models, for example, with the market capitalization method and can be analyzed together with the ROA method. Finally, it is crucial to analyze each industry.

\section{Reference}

AA, O., Helmi, H., \& Mustafa, A. (2019). The association between intellectual capital and financial performance in the Islamic banking industry: An analysis of the GCC banks. International Journal of Islamic and Middle Eastern Finance and Management, 13(1), 75-93. https://doi.org/10.1108/IMEFM-052016-0073
Al-Musali, M. A., \& Ismail, K. N. I. K. (2016). International Journal of Islamic and Middle Eastern Finance and Management Article information: International Journal of Islamic and Middle Eastern Finance and Management, 9(4), 512-531. https://doi.org/10.1108/IMEFM-032015-0029

Anifowose, M., Rashid, H. M. A., \& Annuar, H. A. (2017). Intellectual Capital Disclosure and Corporate Market Value: Does Board Diversity Matter? Journal of Accounting in Emerging Economies, 7(3), 369-398. https://doi.org/10.1108/JAEE06-2015-0048

Bandeira, A. M., \& Afonso, O. (2010). Value of Intangibles Arising from $\mathrm{R} \& \mathrm{D}$ Activities. The Open Behavioral Science Journal, 3(1), 30-43. https://doi.org/10.2174/18749151010030 10030

Barnett, M. L., \& Salomon, R. M. (2006). Beyond Dichotomy: The Curvilinear Relationship Between Social Responsibility and Financial Performance. Strategic Management Journal, 27, 1101-1122.

Barney, J. (1991). Firm Resources and Sustained Competitive Advantage. Journal of Management, 17(1), 99-120.

Bontis, N. (1998). Intellectual capital: an exploratory study that develops measures and models. Management Decision, 36(2), 63-76. https://doi.org/10.1108/00251749810204 142

Bontis, Nick, Keow, W. C. C., \& Richardson, S. (2000). Intellectual capital and business performance in Malaysian industries. Journal of Intellectual Capital, 1(1), 85100.

https://doi.org/10.1108/14691930010324 188

Cabrita, M. do R. M. F., Silva, M. de L. R. da, Rodrigues, A. M. G., \& Dueñas, M. del P. M. (2017). Competitiveness and disclosure of intellectual capital: an empirical research in Portuguese banks. Journal of Intellectual Capital, 18(3), 486-505.

https://doi.org/https://doi.org/10.1108/JI C-11-2016-0112

Chan, S. H., Kensinger, J. W., \& Martin, J. D. 
(1992). The Market Reward Promising R\&D-And Punishes the rest. Journal of Applied Corporate Finance, 5(2), 59-57.

Chen, M. C., Cheng, S. J., \& Hwang, Y. (2005). An empirical investigation of the relationship between intellectual capital and firms' market value and financial performance. Journal of Intellectual Capital, 6(2), 159-176. https://doi.org/10.1108/14691930510592 771

Chu, S. K. W., Chan, K. H., \& Wu, W. W. Y. (2011). Charting intellectual capital performance of the gateway to China. Journal of Intellectual Capital, 12(2), 249-276.

https://doi.org/10.1108/14691931111123 412

Coombs, J. E., \& Iii, P. E. B. (2005). Softwaremodul integriert Karten-material in Fahrerassistenzsysteme. ATZ Automobiltechnische Zeitschrift, 107(78), 616.

DeCarolis, D. M., \& Deeds, D. L. (1999). The impact of stocks and flows of organizational knowledge on firm performance. An empirical investigation of the biotechnology industry. Strategic Management Journal, 20, 953-968.

Edvinsson, L. and Malone, M. (1997). Intellectual Capital. HarperBusiness, New York, NY.

Edvinsson, L., \& Sullivan, P. (1996). Developing a model for managing intellectual capital. European Management Journal, 14(4), 356-364. https://doi.org/10.1016/02632373(96)00022-9

Hamdan, A. (2018). Intellectual capital and firm performance: Differentiating between accounting-based and marketbased performance. International Journal of Islamic and Middle Eastern Finance and Management, 11(1), 139-151. https://doi.org/10.1108/IMEFM-022017-0053

Joshi, M., Cahill, D., \& Sidhu, J. (2010). Intellectual capital performance in the banking sector. Journal of Human Resource Costing \& Accounting, 14(2), 151-170.

https://doi.org/10.1108/14013381011062 649
Kamath, G. B. (2007). The intellectual capital performance of the Indian banking sector. Journal of Intellectual Capital (Vol. 8). https://doi.org/10.1108/14691930710715 088

Kharal, M., Zia-ur-Rehman, M., Abrar, M., Khan, M. S., \& Kharal, M. (2014). Intellectual Capital \& Firm Performance: An Empirical Study on the Oil \& Gas Sector of Pakistan. International Journal of Accounting and Financial Reporting, 4(1), 238. https://doi.org/10.5296/ijafr.v4i1.5759

Kim, S. H., \& Taylor, D. (2014). Intellectual capital vs the book-value of assets: A value-relevance comparison based on productivity measures. Journal of Intellectual Capital, 15(1), 65-82. https://doi.org/10.1108/JIC-04-20130048

Klock, M., \& Megna, P. (2000). Measuring and valuing intangible capital in the wireless communications industry. Quarterly Review of Economics and Finance, 40(4), 519-532.

https://doi.org/10.2469/dig.v31.n2.853

Kong, E., \& Ramia, G. (2010). A qualitative analysis of intellectual capital in social service non-profit organizations: A theory-practice divide. Journal of Management \& Organization, 16(5), 656-676. https://doi.org/10.1017/s1833367200001 796

Leslie, M., \& Holloway, C. A. (2006). The sales learning curve. Harvard Business Review, 7(8), 115-123.

Lev, B., \& Sougiannis, T. (1996). The capitalization, amortization, and valuerelevance of R\&D. Journal of Accounting and Economics, 21(1), 107-138. https://doi.org/10.1016/01654101(95)00410-6

Lu, W. M., Wang, W. K., \& Kweh, Q. L. (2014). Intellectual capital and performance in the Chinese life insurance industry. Omega (United Kingdom), 42(1), 65-74. https://doi.org/10.1016/j.omega.2013.03. 002

Maditinos, D., Chatzoudes, D., Tsairidis, C., \& Theriou, G. (2011). The impact of intellectual capital on firms' market value 
and financial performance. Journal of Intellectual Capital, 12(1), 132-151. https://doi.org/10.1108/14691931111097 944

Nahapiet, J., \& Ghoshal, S. (1998). Social Capital, Intellectual Capital, and The Organizational Advantage. The Academy of Management Review, 23(2), 242-266. https://doi.org/10.2307/259373

Nawaz, Tasawar. (2017). Intellectual capital, financial crisis and performance of Islamic banks: Does Shariah governance matter? International Journal of Business and Society, 18(1), 211-226.

Nawaz, Tasawar. (2019). Exploring the Nexus Between Human Capital, Corporate Governance and Performance: Evidence from Islamic Banks. Journal of Business Ethics, 157(2), 1-21. https://doi.org/10.1007/s10551-0173694-0

Nawaz, Tassawar, \& Roszaini, H. (2017). Determinants of financial performance of Islamic banks: an intellectual capital perspective. Journal of Islamic Accounting and Business Research, 8(2), 130-142. https://doi.org/10.1108/JIABR06-2016-0071

Ozkan, N., Cakan, S., \& Kayacan, M. (2017). Intellectual capital and financial performance: A study of the Turkish Banking Sector. Borsa Istanbul Review, 17(3), 190-198. https://doi.org/10.1016/j.bir.2016.03.001

Roos, G., Pike, S. and Fernstrom, L. (2005). Managing Intellectual Capital in Practice. In Elsevier Butterworth-Heinemann. Burlington, MA.

Roos, G., Roos, J., Edvinsson, L. and Dragonetti, N. Intellectual Capital Navigating in the New Business Landscape, New York University Press (1997).

Sardo, F., \& Serrasqueiro, Z. (2017). A European Empirical Study of The Relationship between Firms' Intellectual Capital, Financial Performance and
Market Value. Journal of Intellectual Capital, 18(4), 771-788.

Shyam-Sunder, L., \& Myers, S. C. (1999). Testing Static Trade-off against Pecking Order Models of Capital Structure. Journal of Financial Economics, 51, 219244.

Subramaniam, M., \& Youndt, M. (2005). The influence of intellectual capital on the types of innovative capabilities. Academy of Management Journal, 48(3), 450-463.

Sveiby, K.-E. (1997). The Intangible Assets Monitor. Journal of Human Resource Costing and Accounting, 2(1), 73-97.

Sydler, R., Haefliger, S., \& Pruksa, R. (2014a). Measuring intellectual capital with financial figures: Can we predict firm profitability? European Management Journal, 32(2), 244-259. https://doi.org/10.1016/j.emj.2013.01.00 8

Sydler, R., Haefliger, S., \& Pruksa, R. (2014b). Measuring intellectual capital with financial figures: Can we predict firm profitability? European Management Journal, 32(2), 244-259. https://doi.org/10.1016/j.emj.2013.01.00 8

Tidd, J., Bessant, J., \& Pavitt, K. (2005). Managing Innovation Integrating Technological, Market and Organizational Change (Third). John Wiley \& Sons, Ltd. Retrieved from https://lccn.loc.gov/2017015568

Ting, I. W. K., \& Lean, H. H. (2009). Intellectual capital performance of financial institutions in Malaysia. Journal of Intellectual Capital, 10(4), 588-599. https://doi.org/10.1108/14691930910996 661

Tiwari, R., \& Vidyarthi, H. (2018). Intellectual capital and corporate performance: a case of Indian banks. Journal of Accounting in Emerging Economies, 8(1), 84-105. https://doi.org/10.1108/JAEE-07-20160067 